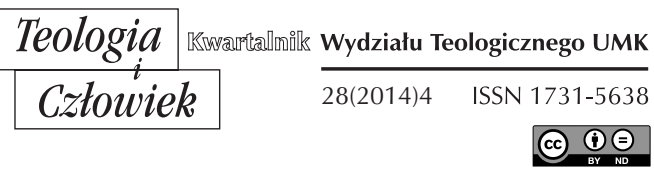

KRZYSZTOF PILARZ*

\title{
SEKULARYZACJA SACRUM I JEJ KONSEKWENCJE PASTORALNO-WYCHOWAWCZE
}

DOI: http://dx.doi.org/10.12775/TiCz.2014.055

Podejmując temat sekularyzacji sacrum, a więc $\mathrm{w}$ jakiejś mierze relacji względem siebie dwóch sfer, sacrum i profanum, poruszamy się po gruncie wyjątkowo niestabilnym metodologicznie. Nie tylko samo zagadnienie sacrum, ale i religijności jako takiej nie doczekało się do tej pory (i chyba raczej się nie doczeka) definicji satysfakcjonującej wszystkie zainteresowane nią osoby. Ze względu na te trudności metodologiczne autor w dużym skrócie i z konieczności w uproszczeniu dokona najpierw swoistej introdukcji do używanych $\mathrm{w}$ artykule pojęcia, aby następnie ukazać zachodzące $\mathrm{w}$ jego przekonaniu deprecjonowanie rzeczywistości sacrum oraz konsekwencje tego faktu z perspektywy pastoralno-wychowawczej i chrześcijańskiej zarazem.

\section{ETYMOLOGIA}

Łacińskie słowo sacrum, podobnie jak sacer, sanctus i sancire, pochodzi prawdopodobnie od rdzenia sak, oznaczającego nadawanie znaczenia,

* Krzysztof Pilarz - doktor nauk humanistycznych, pedagog i teolog, certyfikowany specjalista terapii uzależnień oraz terapeuta TSR, biegły sądowy ds. uzależnień, adiunkt w Zakładzie Pedagogiki Pastoralnej UMK w Toruniu. 
sprawianie, że dana rzecz staje się realna. Terminy te odnosiły się do tego wszystkiego, co dotyczyło bogów, kultu, w tym przedmiotów i ludzi z tym kultem związanych ${ }^{1}$. Za odpowiedniki terminów łacińskich służyły greckie słowa: hagios i hieros, chociaż ich pola semantyczne nie do końca pokrywają się ze sobą, podobnie jak w przypadku hebrajskiego qadosz ${ }^{2}$. Każde z tych słów nawiązuje jednak do relacji ludzkiego bytu wobec rzeczywistości transcendentnej, a niejednokrotnie także immanentnej, co jest ściśle związane z kulturami, z których te terminy pochodzą. Chociaż $\mathrm{w}$ świecie łacińskim i greckim mieliśmy do czynienia z politeizmem, a w świecie Izraelitów z monoteizmem, to jednak w każdej z tych kultur możemy mówić o istotach nadprzyrodzonych w wymiarze osobowym, a przecież w świetle dzisiejszej wiedzy o religii (religiach) wiemy, że nie jest to warunek sine qua non jej istnienia. Ta uwaga jest istotna o tyle, że zazwyczaj termin sacrum jest związany z dychotomicznym postrzeganiem sfery ludzkiej i sfery boskiej oraz nawiązuje do tej drugiej w oparciu o klasyczne definicje religii, opierające się na światopoglądzie chrześcijańskim, czerpiącym u swych korzeni obficie z bogactwa myśli tak semickiej, jak helleńsko-łacińskiej. Nawiązując do tych klasycznych definicji religii, nie sposób nie przywołać najczęstszych propozycji wyjaśnień etymologicznych, pochodzących od Cycerona, Laktancjusza i św. Augustyna. Pierwszy wywodził znaczenie słowa religio z relegere, co miało oznaczać „zwracanie na coś szczególnej uwagi”, „,oddawanie czci bogom”. Laktancjusz nawiązywał do religare, stąd też dla niego ważne było „ponowne związanie z Bogiem”. Augustyn wyprowadzał termin religia od religere w znaczeniu "dokonywania ponownych wyborów"3. Wszystkie zaprezentowane propozycje etymologicznego uchwycenia znaczenia terminu religia (nawet u św. Augustyna, chociaż tutaj musimy wziąć pod uwagę kontekst jego wywodu) wskazują na jej zasadniczą funkcję w ujęciu teistycznym, którą św. Tomasz z Akwinu określił następująco: religio prioprie importat ordinem ad Deum, Zofia Zdybicka zaś nazwała religię jako „realną, osobową i dynamiczną relację człowieka do osobowego Absolutu (Boga), od którego człowiek

* Krzysztof Pilarz - doktor nauk humanistycznych, pedagog i teolog, certyfikowany specjalista terapii uzależnień oraz terapeuta TSR, biegły sądowy ds. uzależnień, adiunkt w Zakładzie Pedagogiki Pastoralnej UMK w Toruniu.

${ }^{1}$ Zob. J. A. Kłoczowski, Sacrum, w: Religia. Encyklopedia PWN, red. T. Gadacz, B. Milerski, wersja elektroniczna (REPWN), Warszawa 2003.

${ }^{2}$ Zob. R. L. Thomas, New American Standard Hebrew-Aramaic and Greek Dictionaries: Update Edition, edycja elektroniczna, Anaheim 1998, nr 6942, 6944.

${ }^{3}$ Zob. A. Bronk, Podstawy nauk o religii, Lublin 2003, s. 105 n. 
jest zależny $\mathrm{w}$ istnieniu i działaniu i który jest - jako Dobro Najwyższe - ostatecznym celem życia ludzkiego"4. Z punktu widzenia nauk o religii (religiach) definicja ta rodzi trudności, co przy okazji syntetycznego ujęcia definicji religii zauważa Andrzej Bronk: „Dzisiaj rozumiemy lepiej, że słowo religia wiąże się tak istotnie $\mathrm{z}$ zachodnim jej rozumieniem, że próby odniesienia go do pozaeuropejskich wierzeń i postaci kultu muszą rodzić trudności i prowadzić do nieporozumień" ${ }^{\prime \prime}$. Trudności te wynikać mogą między innymi z dwóch przyczyn: personalistycznego pojmowania bóstwa (Absolutu, Istoty Najwyższej) oraz wyraźnego podziału i rozdziału sfer sacrum i profanum. Pierwsza przyczyna jest uzasadniona o tyle, że wieloznaczność związana ze zdefiniowaniem zjawiska religii i religijności pozwala zaliczyć do niej takie światopoglądy, które nie muszą odnosić się do osobowego Boga (bogów), a nawet do zagadnienia transcendencji jako takiego, stąd niektórzy badacze do „religii” zaliczają te wszystkie koncepcje, które związane są z doświadczeniem sacrum ${ }^{6}$. Efektem tego jest, jak zauważa Ninian Smart, brak ostrej granicy między religią a niereligią; przynajmniej od kilku dekad trwa też zauważalna dyskusja na temat tzw. religii świeckich, chociaż już w 1762 roku Jan-Jakub Rousseau pisał w IV księdze Umowy społecznej o:

czysto społecznym wyznaniu wiary, którego artykuły zwierzchnik ma prawo określić, nie jako właściwe dogmaty religijne, lecz jako przekonania socjalne, bez których niepodobna być dobrym obywatelem i wiernym poddanym. Nie mogąc nikogo zmusić do wierzenia $w$ nie, może wypędzić z państwa każdego niewierzącego; może go wygnać nie jako bezbożnego, lecz jako nieuspołecznionego, niezdolnego do szczerego kochania ustaw, sprawiedliwości i do poświęcenia w razie potrzeby swego życia obowiązkowi ${ }^{8}$.

${ }^{4}$ Z. J. Zdybicka, Człowiek i religia. Zarys filozofii religii, Lublin 1993, s. 302. Por. św. Tomasz z Akwinu, Summa teologiczna, II, II, 81, 1.

${ }^{5}$ A. Bronk, dz. cyt., s. 110.

${ }^{6}$ Warto tu wymienić głównie reprezentantów fenomenologicznego ujęcia religii, takich jak G. van der Leeuw, M. Scheler, R. Otto czy F. D. E. Schleiermacher; sam M. Eliade przy definiowaniu religii pisał, że słowo to „nie oznacza bynajmniej wiary w Boga, bogów czy duchy, ale [...] odnosi się do doświadczenia sacrum, wiąże się przeto z pojęciami bytu, znaczenia i prawdy". Zob. M. Eliade, W poszukiwaniu historii i znaczenia religii, tłum. A. Grzybek, Warszawa 1997, s. 5.

7 Zob. N. Smart, The Science of Religion and Sociology of Knowledge. Some Methodological Questions, Princeton 1973, s. 6.

8 J.-J. Rousseau, O umowie społecznej czyli zasady prawa politycznego, tłum. 
Nie wdając się dalej w dywagacje dotyczące samego pojęcia religijności, jako że znacznie przekraczałyby one ramy samego artykułu, podsumujmy w tym miejscu za Religiq. Encyklopediq PWN, iż jest to "zjawisko różnorodnie definiowane i opisywane z wielu perspektyw" ${ }^{\prime \prime}$. Trzeba jednak zauważyć, że druga z przyczyn trudności związanych z zachodnim pojmowaniem religii, czyli wyraźny rozdział sfer sacrum i profanum, jest - jakkolwiek często przytaczany przez wielu badaczy ${ }^{10}$ - problemem pozornym. Aby ukazać jego pozorność, niezbędne jest odniesienie się do potocznego rozumienia tych rzeczywistości.

\section{POZORNA DYCHOTOMIA SACRUM I PROFANUM}

W ujęciu potocznym, ale i reprezentowanym przez badaczy krytykujących tzw. teistyczne rozumienie religii (utożsamiane $\mathrm{z}$ religijnością Zachodu), o którym było napisane wcześniej, sacrum i profanum są dziedzinami rozłącznymi. Sacrum postrzegane jest jako to, co święte, religijne w ścisłym znaczeniu tego słowa, to jest odnoszące się wprost do sfery boskiej. Według takiego podejścia do sacrum zaliczać będziemy nie tylko doktrynę czy określone koncepcje bóstwa, ale relację pomiędzy nim a człowiekiem i to wszystko, co ją umożliwia bądź ułatwia, czyli rzeczywistość kultyczną (wliczając w to określone miejsca, czas, rytuał etc.). Z relacyjnością tą związane są także konkretne wymagania bóstwa wobec wierzących, co przekłada się na wywodzące się z doktryny normy religijne, zasady moralne (etyczne), kształt wspólnoty religijnej (z ewentualną hierarchią grupy kapłańskiej, jeżeli takowa występuje). Współcześnie w świecie zachodnim podkreśla się subiektywność i indywidualność w postrzeganiu tej sfery, co wyraża się w przekonaniu, że „wiara to prywatna sprawa każdego człowieka". Dla kontrastu profanum to szeroko rozumiana sfera świecka, w założeniu niezależna od sfery sacrum. Kategoria świeckości, zwana też laicką (od francuskiego laïcité $e^{11}$ ), z założenia

A. Peretiatkowicz, Łódź 1984, s. 120 n. Przytoczone słowa Rousseau kojarzą się z definicją podaną przez Paula Tillicha, rozumiejącego religię jako "ostateczną troskę", co otwiera drogę do postrzegania w kategoriach religijnych całego spektrum ideologii. Zob. A. Bronk, dz. cyt., s. 121.

${ }^{9}$ A. Bronk, Religia, w: REPWN.

${ }^{10}$ Zob. np. S. Kamiński, Z. J. Zdybicka, Definicja religii a typy nauk o religii, „Roczniki Filozoficzne” 22 (1974), z. 1, s. 103-160.

${ }^{11}$ Chociaż studia semantyczne przeprowadzone przez P. Fiala ukazują, że 
ma być bardziej obiektywna, wolna od naleciałości religijno-ideologicznych i oparta na ludzkim rozumie, a nie wierze. $W$ takim rozumieniu sfera profanum może akceptować różnorakie przejawy ludzkiego życia odnoszące się do rzeczywistości sacrum pod warunkiem, że nie będą one kolidować z nadrzędnym paradygmatem świeckości w życiu publicznym.

\section{SACRUM W DOBIE POSTMODERNIZMU}

Powyższe założenia znajdują swoje rozwinięcie w postmodernistycznej kontestacji rzeczywistości. O ile sam modernizm był z założenia próbą afirmacji ludzkiego rozumu, o tyle nie trzeba specjalnie udowadniać, że afirmacja ta okazała się fiaskiem. Symboliczna detronizacja Boga jako Twórcy rzeczywistości i norm miała doprowadzić do "wyzwolenia” człowieka, tymczasem postmodernistyczny "zwrot antropologiczny", pozbawiony swoistego konstant, punktu odniesienia, jakim była religia, doprowadził do niespotykanego wcześniej relatywizmu, a proklamowana przez postmodernizm wolność zamieniła się w chaotyczną i pozorną dowolność. Pozorną, gdyż postmodernizm, odrzucając programowo wszelkie paradygmaty i metateorie, sam stał się nosicielem takiego paradygmatu. Trafnie podsumował istotę nurtu postmodernistycznego i proklamowanej przez niego „wolności” Jacek Kaczmarski w utworze Postmodernizm: „Wszystko wolno, hulaj dusza! [...] Oj, nie wolno rzeczy wielu, kiedy celem jest brak celu, zwłaszcza jeśli duszy nie ma, i to wszystko na ten temat”. W kontekście postmodernistycznego „zwrotu antropologicznego" można zadać pytanie, czy jest w nim miejsce na sacrum? Zauważalne w Europie Zachodniej odchodzenie od zbiorowego przeżywania doświadczeń religijnych na rzecz prymatu subiektywnych, indywidualnych odczuć ${ }^{12}$ wydaje się nie przeczyć klasycznemu już ujęciu sacrum w wydaniu Rudolfa Otta jako misterium tremendum et fascinans, a przy tym także augustum (wartość absolutna). Tak rozumiane sacrum

termin ten pochodzi od średniowiecznego lay i był, zwłaszcza w kontekście rodzącego się protestantyzmu, synonimem dla séculier. Zob. J. Baubérot, Pochodzenie i narodziny świeckości, tłum. K. Pachniak, w: Encyklopedia religii świata (ERŚ), red. prow. W. Żakowski, t. 2: Zagadnienia problemowe, Warszawa 2002, s. 2100.

${ }_{12}$ Zob. M. Meslin, Doświadczenie religijne, tłum. G. Majcher, w: ERŚ, t. 2, s. 2253-2265; F. Raphaël, G. Herberich-Marx, Pielgrzymki, tłum. K. Pachniak, w: ERŚ, t. 2, s. 1984-1990 (zwł. akapit Przemieszczenia sacrum w obecnym świecie, s. 1989 n.). 
trwoży, wywołuje lęk, a nawet przeraża, jednocześnie fascynując człowieka, skłaniając go do osobistego zaangażowania w poznawaniu tej rzeczywistości, będącej dla niego szczególną tajemnicą - stąd też Otto nawiązywał do doświadczenia numinotycznego (samo sacrum nazywa także numinosum od greckiego numen, bóstwo) ${ }^{13}$. Niemalże równolegle z pierwszym wydaniem przez Otta Świętości Nathan Söderblom rzeczownik ten nazwał „,najważniejszym słowem religii"; stwierdził, że świętość ,jest może nawet bardziej istotna od pojęcia Boga"14. I tutaj też pojawia się problem. Jeżeli postrzegać będziemy sferę sacrum jako odnoszącą się, jak domaga się tego idea społeczeństwa (państwa) świeckiego, tylko do doświadczenia prywatnego, dojdziemy do istotnej trudności egzystencjalnej. Człowiek w społeczeństwie zlaicyzowanym jest zmuszony prezentować względem tego społeczeństwa postawę redukcyjną odnośnie do przeżywanej przez siebie rzeczywistości sacrum; jego normy, wartości i przekonania mogą być akceptowane o tyle, o ile nie stoją w sprzeczności z ideą świeckości czy, co dziś modne, „neutralności światopoglądowej". Tym samym, chociaż teoretycznie istnieć może wiele różnych sfer sacrum (w zależności od poszczególnych religii, koncepcji bóstw, form kultu etc.), to są one praktycznie podporządkowane sferze profanum, z założenia będącej antropocentryczną, stawiającą człowieka w centrum tworzonych przez siebie konstruktów społecznych, etycznych i wszelkich innych. Tymczasem doświadczenie sacrum, dotykając człowieka do głębi, wpływa także na jego przekonania i sposób funkcjonowania w świecie tak, iż w pewien sposób staje się on sacrocentryczny. Takie podejście jest z punktu widzenia paradygmatu postmodernistycznego niedopuszczalne, gdyż zakłada, że człowiek może być w pewien sposób zależny od sił większych od niego. Religia i wiara zostają utożsamione, jak mówił Friedric Daniel Ernst Schleiermacher, z „poczuciem absolutnej zależności"15i jako takie są postrzegane pejoratywnie wobec postmodernistycznej „idei bezideowości”. Jedynym rozwiązaniem w takiej sytuacji, gdy chce się zachować paradygmat postmodernistyczny, jest zgoda na antropocentryczne quasi-sacrum (w nawiązaniu do quasi-religii Paula

${ }^{13}$ Zob. R. Otto, Świętość. Elementy irracjonalne w pojęciu bóstwa $i$ ich stosunek do elementów racjonalnych, tłum. B. Kupis, Warszawa 1999.

${ }^{14}$ N. Söderblom, Holiness, w: Encyclopaedia of Religion and Ethics, red. J. Hastings, t. 6, London 1913, s. 731-759.

${ }^{15}$ Za: A. Bronk, Podstawy nauk o religii, s. 112. 
Tillicha, będących $\mathrm{w}$ istocie ideologiami ${ }^{16}$, w którym to, co początkowo określane jest jako boskie, z założenia nie może być transcendentne, gdyż ostatecznie okazuje się na wskroś ludzkie, czego starał się dowodzić Ludwig Fauerbach w swojej Istocie chrześcijaństwa ${ }^{17}$. Idąc za słowami Henriego de Lubaca, „człowiek eliminuje Boga, by samemu odzyskać panowanie nad ludzką wielkością"18. W ten sposób samo sacrum staje się relatywne, ale efektem jego podporządkowania profanum nie jest, paradoksalnie, wyrugowanie z ludzkiego życia religii, lecz - przy dokonaniu rewaloryzacji semiotycznej, a nawet semantycznej pojęcia sacrum dyskusyjna sakralizacja rzeczywistości ${ }^{19}$. Dyskusyjna, gdyż „współczesny świat zachodni - jak pisze Andrzej Bronk, komentując koncepcje Mircei Eliadego - zakrywając sacrum i/lub identyfikując je z profanum, osiągnął ostateczny etap desakralizacji”20.

\section{NIEROZKĄCZNOŚĆ SACRUM I PROFANUM}

Powyższa uwaga pozwala w bardziej pogłębiony sposób wrócić do pozornej dychotomii rzeczywistości sacrum i profanum, chociaż nie

${ }^{16}$ Por. tamże, s. 121.

${ }^{17}$ Ludwig Feuerbach pisze: „Jeśli jednak religię, naszą świadomość Boga, określamy jako samowiedzę człowieka, to nie należy tego rozumieć w ten sposób, by człowiek religijny uświadamiał sobie bezpośrednio, że jego świadomość Boga jest samowiedzą jego własnej istoty, gdyż właśnie nieuświadomienie sobie tego faktu warunkuje swoistą istotę religii. [...] religia jest pierwszą, mianowicie pośrednią samowiedzą człowieka. [...] Człowiek transponuje swą istotę najpierw poza siebie, zanim ją odnajdzie w sobie. Własną istotę uprzedmiotawia sobie najpierw w postaci innej istoty. [...] Historyczny postęp polega $\mathrm{w}$ religii wobec tego na tym, że to, co w dawniejszej religii było uważane za coś obiektywnego, jest później czymś subiektywnym, to znaczy, że to, co oglądano i czczono jako Boga, poznano później jako ludzkie". L. Feuerbach, Istota chrześcijaństwa, tłum. A. Landman, Warszawa 1959, s. 56-57.

${ }^{18}$ H. de Lubac, Le drame de l'humanisme athée, Paris 1963, s. 20. Cytat za: Y. Ledure, Nowy status religijności, tłum. J. Danecki, ERŚ, t. 2, s. 2363.

19 Póki co pozostajemy na polu nauk o religii, stąd też nie dokonuję tu jeszcze oceny takiego podejścia z punktu widzenia sacrum w ujęciu chrześcijańskim.

20 A. Bronk, Podstawy nauk o religii, s. 274. Inna sprawa, że wśród krytyków Eliadego nie brakuje takich, którzy uważają, że takiej desakralizacji dokonał sam Eliade, przyjmując tak szeroką definicję religii, że właściwie utożsamił ją z kulturą, a samo pojęcie sacrum jest w jego pracach niejednoznaczne (raz postrzega je jako „element w strukturze świadomości, nie zaś etap w jej historii”, a innym razem jako rzeczywistość "transcendentną" i „transpersonalną"). Tamże, s. 285 n. 
w oderwaniu od postmodernistycznych i subiektywistycznych założeń. Uważne przyjrzenie się koncepcjom dotyczącym tych dwóch rzeczywistości, zwłaszcza w ujęciu Mircei Eliadego, który w swoich pracach poświęcał im szczególnie dużo uwagi, może zakończyć się konsternacją. Przypomnijmy, że według Eliadego elementem zawsze obecnym, rzeczywistym (realnym) i stałym jest nie profanum, a sacrum. Profanum, rozumiane jako ludzkie dzieje, ale także jako nieporządek, zjawiskowość i zmienność („przygodność”, jak określiłby to św. Tomasz z Akwinu), jest de facto mniej rzeczywiste niż sacrum, więcej nawet - o ile sacrum określilibyśmy jako byt, profanum staje się nie-bytem. Niemniej jednak profanum - dzieje są koniecznym warunkiem rozumienia sacrum. Wprowadzony przez Eliadego do nauk o religii termin hierofania (i jej przejawy: ontofania, kratofania, teofania), to jest „ukazanie (objawienie) się świętości", wskazuje na miejsce uzewnętrznienia się sfery świętości w profanum. Idąc śladem myśli Eliadego, zauważyć tu można pewną niekonsekwencję, będącą źródłem wspomnianej już konsternacji ${ }^{21}$. O ile sacrum to faktycznie jakiś zbiór elementów ze sfery profanum umożliwiający kontakt ze świętościa, to wówczas można zauważyć niekonsekwencję Eliadego w definiowaniu sacrum. $Z$ jednej strony jest ono rzeczywistością prowadzącą dialektykę z profanum i zupełnie od niej inną, z drugiej wydaje się zbiorem elementów, specjalnie wyznaczonym i oddzielonym (por. hebr. qadosz), tegoż profanum. Dojść można do wniosku, że albo musiałaby istnieć jakaś gradacja sacrum (w takim ujęciu Eliademu byłoby blisko do Platona - przejawy sacrum w naszym świecie, realizujące się poprzez elementy profanum niczym cienie na ścianie platońskiej jaskini, ukierunkowywałyby na sacrum absolutne, niezmienne), albo też samo sacrum wskazywałoby na element będący poza nim, rzeczywiście boski i niezmienny, którego sacrum byłoby tylko emanacją (tu nawiązywalibyśmy do plotyńskich hipostaz). Fakt ten, nie tylko w odniesieniu do Eliadego, ale koncepcji sacrum jako takiej, zauważyła już Z. Zdybicka, pisząc w kontekście definiowania zjawiska religii, że dla jego pełnego określenia „konieczne jest przyjęcie rzeczywistości transcendentnej w stosunku do sacrum, a więc boskości"22. Jeżeli nie założymy istnienia tej rzeczywistości transcendentnej (to konieczna uwaga) w stosunku do sacrum, wówczas dokonująca się w naszych czasach postmodernistyczna hierofania jawi się

${ }^{21}$ Zob. Hierophany, w: The Encyclopedia of Religion, red. M. Eliade, L. E. Sullivan, Macmillan-New York-London 1987, t. 6, s. 313-317.

${ }^{22}$ Z. I. Zdybicka, Człowiek $i$ religia. Zarys filozofii religii, Lublin 1977, s. 199. 
groteskowo i przerażająco zarazem. O ile w modelowym ujęciu hierofania jest objawieniem boskości, o tyle w postmodernizmie będzie opierała się ona na jej negacji. Postmodernistyczna hierofania będzie, przy negacji bóstwa, jednoczesnym uświęceniem najdoskonalszego znanego bytu w tym wypadku człowieka; on to niejako „objawi się" sam sobie jako najdoskonalsza istota. Doprowadzić to może do niebezpiecznego redukcjonizmu, gdyż poszukiwania sacrum nie będą już skierowane w metaforycznie bądź dosłownie pojmowane niebo, jako miejsce zamieszkania Absolutu i absolutnych, niezmiennych wartości, do których odkrywania powołany jest człowiek. Przy zajęciu przez człowieka miejsca bóstwa jedyną pewną i niezmienną cechą człowieka, mogącą pełnić funkcję niezmiennego sacrum, będzie śmierć - wszystko inne będzie relatywne i w odniesieniu do poszukiwania sacrum niewarte uwagi, prowadząc do zaniku zainteresowania wartościami absolutnymi. Proces taki dokonuje się już w kulturze zachodniej, nie bez powodu nazwanej przez Jana Pawła II „kulturą śmierci” („cywilizacją śmierci”) ${ }^{23}$, a samo zagadnienie śmierci cieszyło się i cieszy dużym zainteresowaniem współczesnej filozofii, z Heideggerowskim Dasein (Byciem-ku-Śmierci) i związaną z nim Trwogą (Angst) na czele ${ }^{24}$.

\section{SACRUM, PROFANUM I DIVINUM}

Podsumowując dotychczasowe rozważania, w odniesieniu do rzeczywistości sacrum - w celu uniknięcia jej relatywizacji - niezbędne wydaje się odwołanie do rzeczywistości nadrzędnej, boskiej, określanej jako divinum. Jak jednak, także w działalności pastoralnej i wychowawczej, określić - już z chrześcijańskiego punktu widzenia - wzajemne relacje pomiędzy sacrum, profanum i divinum? Nietrudno przecież wyobrazić sobie sytuację, kiedy to sacrum faktycznie jest zrelatywizowane, a jednocześnie odnosi się do divinum, które samo w sobie ,jest jakie jest",

${ }^{23}$ Jan Paweł II, Evangelium vitae, nr 95.

${ }^{24}$ Nie sposób nie nawiązać tu ponownie do misterium tremendum et fascinans R. Otta. O ile jednak u Otta owe misterium stanowi wartość nadrzędną (augustum), o tyle u Heideggera jest wyrazem tragedii ludzkiego losu skazanego na niebyt. U Otta człowiek poprzez sacrum odkrywa sens swego życia, u Heideggera przeciwnie, co prowadzi do ucieczki określanej jako Upadanie (Verfallen). Ta droga do nihilizmu nie musi prowadzić do całkowitego niebytu, czemu Heidegger dał wyraz m.in. w Liście o humanizmie. 
będąc wprost nieuchwytne dla człowieka z jakiegoś powodu (takiego jak na przykład jego ewentualna niezdolność do rozumowego ogarnięcia divinum, co wydaje się założeniem jak najbardziej logicznym - jeżeli człowiek byłby w stanie objąć coś rozumem, wówczas nie mielibyśmy do czynienia z rzeczywistą transcendencją̨). By nie szukać daleko, jako przykład mogą służyć wielkie religie monoteistyczne, odnoszące się do divinum, aczkolwiek w różny sposób funkcjonujące w zakresie identyfikacji i określenia sacrum. Naszą uwagę zwróćmy jednak w kierunku chrześcijaństwa, które $\mathrm{w}$ przekonaniu autora niniejszego artykułu nie tylko w najpełniejszy sposób dotyka relacji pomiędzy profanum, sacrum i divinum, ale też doskonale wpisuje się $\mathrm{w}$ dyskusję nad modernistyczną i postmodernistyczną sekularyzacją, proponując konkretne i interesujące, nawet dla osoby niewierzącej, rozwiązania.

Po pierwsze, spójrzmy na chrześcijaństwo w świetle dychotomii sacrum - profanum. Jak zauważa A. Bronk, „radykalne przeciwstawianie dziedziny sacrum i profanum, nieba i świata, jest znane chrześcijaństwu"26. Badacz przytacza na poparcie tej tezy kilka wersetów biblijnych, m.in. z Ewangelii wg św. Jana: „Jeśli świat was nienawidzi, to wiedzcie, że mnie wcześniej znienawidził niż was. Gdybyście byli ze świata, świat kochałby to, co do niego należy. Wy jednak nie jesteście ze świata, gdyż wybrałem was z tego świata dla siebie. Dlatego świat was nienawidzi" (J 15,18-19, BPaul), czy z Pierwszego Listu św. Jana: „Nie miłujcie świata ani tego, co jest na świecie. Jeżeli ktoś miłuje świat, nie ma w nim miłości Ojca” (1 J 2,15, BPaul). Trzeba tu przypomnieć, że „świat” (greckie

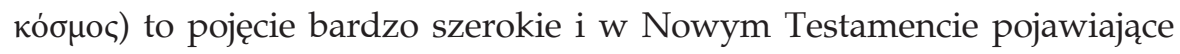
się w różnych kontekstach i znaczeniach. Ogólnie nawiązuje ono do jakiegoś uporządkowania (także w znaczeniu przyozdabiania, jak w 1 P 3,3), może oznaczać cały świat, świat człowieka, jakiś aspekt rzeczywistości, może też być synonimem świata grzesznego, odrzucającego Boga ${ }^{27}$. Po

${ }^{25} \mathrm{Na}$ marginesie dodajmy, że divinum rozumiane jako coś transcendentnego, „nadprzyrodzonego”, czyli innego niż „Zwykła” rzeczywistość, w której funkcjonuje człowiek, jest charakterystyczne głównie dla języka łacińskiego i jego pochodnych (zob. łac. supernaturalis). W religiach Wschodu takie założenie byłoby niejednokrotnie wątpliwe, a nawet nie do przyjęcia. Nawet nie nawiązując do kultur innych niż zachodnia, zauważyć można, zwłaszcza na gruncie psychologii, koncepcje podobne do tych utożsamianych ze Wschodem (np. trychotomiczne ujęcie osobowości w psychoanalizie z superego na czele; psychologia głębi C. G. Junga).

${ }^{26}$ A. Bronk, Podstawy nauk o religii, s. 113.

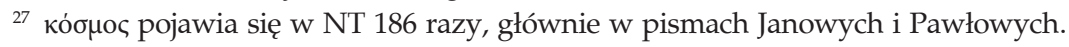


wnikliwym przedstawieniu znaczenia tego słowa nie tylko $\mathrm{w}$ greckim tekście biblijnym, ale w szeroko rozumianej greckiej literaturze antycznej,

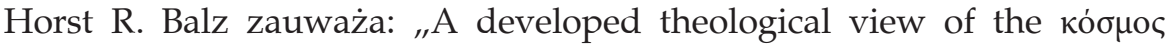
is to be seen especially in the Pauline and Johannine traditions, where

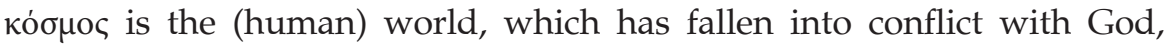
and for which God has acted to bring redemption and reconciliation"28. W tym upadłym świecie znajduje się „pożądliwość ciała, pożądliwość oczu i pycha ze spraw doczesnych" (1 J 2,16, BPaul). Wobec powyższego nie tyle sam świat, rozumiany jako kosmos, jest opozycyjny względem Boga (gdyż On go przecież stworzył i określił, że jest dobry), ale staje się taki poprzez działanie człowieka. Tym samym profanum w kontekście biblijnym można przedstawić jako należące do rzeczywistości stworzonej przez Boga, ale jednocześnie to, które niejako „zapomniało" swoje pochodzenie, a tym samym i prawdziwy sens. Człowiek traci kontakt z Bogiem poprzez grzech pierworodny, tworząc wycinek rzeczywistości, w którym próbuje się ukryć przed Bogiem. Widzimy tu, że myśl biblijna koresponduje częściowo z koncepcjami Eliadego - „pierwszy Adam”, istota żyjąca z Bogiem, odpowiada archetypicznemu człowiekowi archaicznemu. Dopiero kardynalny błąd, polegający na nadaniu znaczenia sacrum (sic!) czemuś, co przeczy nie tylko samemu sacrum, ale i divinum, doprowadza do upadku człowieka. W świecie stworzonym dla niego identyfikuje on drzewo poznania dobra i zła jako źródło tajemnicy, do którego Bóg nie dał mu dostępu, tajemnicy mogącej uczynić istotę ludzką równą Bogu. Aby dokonała się taka zmiana w postrzeganiu owego drzewa, konieczne było zasianie wątpliwości w swojego Stwórcę, odrzucenie wiary $\mathrm{w}$ to, że chce on dla człowieka dobrze. Nastąpiła $\mathrm{w}$ ten sposób tragiczna, egzystencjalna zmiana - w ludzkim czynie następuje negacja boskości (ogród Eden staje się obcy, sacrum zamienia się w ludzkich oczach w profanum), a jedyny element niosący ewentualność profanum drzewo poznania dobra i zła - staje się sacrum ${ }^{29}$. W taki sposób historia zbawienia jawi się jako dialektyka sfer sacrum i profanum, zmierzająca do

Zob. H. Balz, кó $\mu о \varsigma$, w: R. B. Balz, G. Schneider, Exegetical Dictionary of the New Testament, Grand Rapids, Mich., 1990, vol. 2, s. 309-312.

28 Tamże, s. 311.

${ }^{29}$ Por. w tym kontekście słowa papieża Franciszka z jego encykliki Lumen fidei (LF): „I tak człowiek zrezygnował z poszukiwania wielkiego światła, by zadowolić się małymi światełkami, które oświecają krótką chwilę, ale nie są zdolne do otwarcia drogi. Gdy brakuje światła, wszystko staje się niejasne, nie można odróżnić dobra od zła, drogi prowadzącej do celu od drogi, na której błądzimy bez kierunku" (LF, nr 3). 
ponownego odkrycia właściwego znaczenia i miejsca świętości. Inaczej niż w przypadku Eliadego, gdzie przeciwstawieni są sobie człowiek archaiczny i człowiek historyczny, w myśli biblijnej człowiek żyje w historii i w historii dokonuje się też jego zbawienie - nie w ujęciu gnostyckim, jak chociażby u Kurta Rudolpha, gdyż to zbawienie dokonuje się w konkretnym momencie, mając za punkt krytyczny wydarzenie śmierci i zmartwychwstania Chrystusa. W Nim świat oddalony od Boga znów do Boga wraca, więcej nawet - następuje jego przebóstwienie. Na drodze wiary człowiek poznaje rzeczywistość, a im bardziej ją poznaje, tym bardziej zdaje sobie sprawę z nieadekwatności do niej kategorii profanum. Bóg nie jest już istotą obcą i daleka, której miejsce jest w świątyni, przeciwnie - to nie świątynia z kamienia, ale ludzkie serce staje się mieszkaniem Boga ${ }^{30}$.

Konieczna jest w tym miejscu druga uwaga. Wcześniej zaznaczyliśmy, że w świecie bez Boga (tu utożsamionego z profanum) najdoskonalszą istotą staje się człowiek, a najpewniejszą rzeczą na świecie, jedynym konstant - śmierć. W ten sposób, co może się wydawać paradoksalne, „kultura śmierci” w szczególny sposób predysponowana jest do otwarcia się na chrześcijaństwo. Tam, gdzie wyczerpane są już wszelkie możliwości, gdzie ludzki rozum wobec śmierci musi uznać się za pokonany, pojawia się konkretna Osoba - Jezus Chrystus, który wchodzi w mroki śmierci, aby objawić życie. Tutaj chrześcijanin staje już nie wobec którejś z kolei koncepcji religijnej czy mitu, ale konkretnego faktu. Chociaż w starożytności było wiele kultów, świadectwo Jezusa, jak zauważa papież Franciszek, było rzeczywiście wyjątkowe. Cytowany przez niego Justyn Męczennik miał powiedzieć: „Nie spotkano nikogo gotowego umrzeć za swą wiarę w Słońce" ${ }^{\prime \prime}$. Owszem, w obecnym świecie metafora wiary chrześcijańskiej jako światła w ciemności może się wydawać nieadekwatna, gdyż poruszamy się w otoczeniu stroboskopowych, neonowych wartości, gdzie pozornie wszystko jest ,jasne” tak bardzo, jakby całkowicie negowano mrok, a same światła nieustannie zmieniają kolory, drażniąc zmysł wzroku i, zamiast oświetlać drogę, powodują jeszcze większe zagubienie. W świetle rozumu, co paradoksalne, „wiara została w końcu skojarzona z ciemnością”, z „iluzją światła, utrudniającą nam, ludziom wolnym, drogę ku przyszłości"32. Takie potoczne rozumienie i wiary, i rozumu, ocierające się o skrajności w postaci racjonalizmu z jednej

\footnotetext{
${ }^{30}$ Por. Dz 17,24 n; Rz 8,9-11; 1 Kor 3,16.

$31 \mathrm{LF}, \mathrm{nr} 1$.

${ }^{32} \mathrm{LF}, \mathrm{nr} 2-3$.
} 
strony i fideizmu z drugiej, nie ma nic wspólnego z wiarą chrześcijańską, co wyraźnie przypomniał Jana Paweł II w encyklice Fides et ratio, odnosząc te dwie sfery, na zasadzie ich wzajemnej komplementarności, do poznania prawdy ${ }^{33}$. Katechizm Kościoła Katolickiego, kilkukrotnie podając definicje wiary, podkreśla jej relacyjność wobec prawdy, Boga, ale i jej dobrowolność oraz charakter wspólnotowy ${ }^{34}$. Chociaż tekst Katechizmu nie mówi o tym wprost, wiara jest ściśle skorelowana z nadzieją i zaufaniem, a nie ma zaufania większego niż to, które dokonuje się w miłości - stąd też do pełnego określania wiary niezbędne jest łączenie jej z pozostałymi cnotami teologalnymi, co wiąże się z określonymi wyzwaniami pastoralno-wychowawczymi.

\section{WYZWANIA PASTORALNO-WYCHOWAWCZE}

Wobec sekularyzacji sacrum w działaniach pastoralno-wychowawczych nie wystarczy dostosowanie języka do nowych form dialogu. Bycie pasterzem i wychowawcą w świecie relatywizmu opierać się musi nie tylko na mówieniu o Bogu (wąskie znaczenie słowa "przepowiadanie”), gdyż człowiek nie tylko słucha, ale i patrzy. Na te dwa rodzaje poznania zwraca uwagę papież Franciszek w swojej pierwszej encyklice ${ }^{35}$. Jeżeli to, co słyszane, nie idzie $\mathrm{w}$ parze $\mathrm{z}$ tym, co widziane, wprowadzi nieufność, która będzie przeszkodą na drodze do przyjęcia wiary. Dlatego też, nawiązując do tematu artykułu, nie będziemy tu pisać o trudnościach w działalności pastoralno-wychowawczej związanych z kształtem dzisiejszego świata, ale postawimy postulat, że współcześnie, może bardziej niż kiedyś, potrzeba rzeczywistego świadectwa ze strony tych, którzy taką działalność prowadzą lub zamierzają prowadzić. Wielkie przykłady wiary biblijnej, by wymienić tylko Abrahama i Maryję, są wyzwaniem dla dzisiejszego świata, dla każdego kapłana, katechety, wychowawcy. W dawaniu świadectwa należy jednak zachować elementarny porządek.

33 Jan Paweł II, Fides et ratio, nr 1.

${ }^{34}$ Zob. np. KKK, nr 150: „Wiara jest najpierw osobowym przylgnięciem człowieka do Boga; równocześnie i w sposób nierozdzielny jest ona dobrowolnym uznaniem całej prawdy, którą Bóg objawił”; nr 162: „Wiara jest darem danym człowiekowi przez Boga”; nr 166: „Wiara jest aktem osobowym, wolną odpowiedzią człowieka na inicjatywę Boga, który się objawia. Wiara nie jest jednak aktem wyizolowanym. Nikt nie może wierzyć sam, tak jak nikt nie może żyć sam" etc. (zwł. nr 176-184).

${ }^{35} \mathrm{LF}, \mathrm{nr} 29-31$. 
Świadectwo wiary zakłada wiarę, bez niej świadectwo jest jałowe i bezsilne, więcej nawet - staje się świadectwem fałszywym, antyświadectwem. Aby być świadkiem wiary, aby wyjść z tego, co znane i pewne, ku temu, co zaledwie obiecane, aby wypowiedzieć w swoim życiu fiat - trzeba zaufać, a by zaufać - poznać i pokochać. Tutaj też dochodzimy do znaczenia chrześcijańskiego sacrum. Człowiek poszukujący Boga może zostać do niego przyciągnięty przykładem wierzących, ale postawa wierzących musi wynikać z żywej wiary w łączności z całą Tradycją Kościoła. Bez odniesienia do divinum widzialna sfera sacrum może być postrzegana $\mathrm{w}$ najlepszym razie jako interesujący przejaw kultury ludowej, w najgorszym - jako system mający na celu wykorzystywanie ludzi prostych i naiwnych i czerpanie $\mathrm{z}$ ich przekonań różnorakich profitów. W takim, bardzo często spotykanym ujęciu, kapłan nie jest już postrzegany jako pasterz, ale jak wilk. Z pewnością nie jest łatwo być autentycznym chrześcijaninem. Już niemalże powszechnie wartość człowieka mierzona jest jego stanem majątkowym, stąd też nie tylko świeccy, ale i osoby duchowne ulegają pokusie sukcesu według kryteriów świata, zabiegając o szeroko rozumiany sukces osobisty - jeżeli nie finansowy, to na przykład naukowy. Praktyka życiowa zbyt często pokazuje, że ewangeliczne teksty odnoszące się od faryzeuszy i uczonych w Piśmie niepokojąco pasują do wielu z tych, którzy mają być świadkami żywej wiary i to właśnie ich zsekularyzowane podejście do sacrum wyrządza szczególnie dużo szkód w sercach tych, którzy szukają żywego Boga. I odwrotnie - bezkompromisowe pójście za Chrystusem owocuje żywymi owocami Ducha Świętego i przyciągnięciem do niego wielu ludzi poszukujących prawdziwych wartości i sensu życia, czego doskonałym przykładem jest reakcja na pontyfikat papieża Franciszka i na jego proste, wydawałoby się wręcz, że oczywiste i banalne - przypominanie o fundamentach chrześcijańskiego posługiwania. Rzeczywiście, mówienie o miłości bez jej osobistego doświadczenia, o wierze bez zakorzenienia w praxis wydaje się nie tylko niepełne, ale wręcz pozbawione zasadniczego pierwiastka konstytuującego prawdziwość tego, co głoszone - świadectwa żywego uczestnictwa. Owszem, rezygnacja ze świata i życie zgodnie z radykalizmem Ewangelii nie jest łatwe, ba - po ludzku wręcz niemożliwe, ale przecież „wszystko mogę w Tym, który mnie umacnia” (Flp 4,13). Pytanie tylko, czy naprawdę w to wierzę i czy tym żyję (por. Jk 2,17)? A jak Ty odpowiesz na to pytanie, Czytelniku? 


\begin{abstract}
The article aims to present some thoughts about secularization of sacrum and relation between sacrum, profanum and divinum. The secularization of sacrum is a serious problem in pastoral and educational work, especially in postmodernism and its "anthropological direction". The trouble with sacrum is deeply rooted not only in West culture and civilization, but also within Christian community. The only cure in this crisis of sacrum (and, in fact, profanum) is remembered about divinum, God himself, who is not a myth or philosophical conception, but real person. To do it, it's a necessary to take care about true Christian life and education, fully of love, faith and hope. Only true Christian can be a faithfully witness of Christ.
\end{abstract}

Keywords: Sacrum, profanum; divinum; faith; Christian education.

\begin{abstract}
Abstrakt: W artykule przedstawiono kilka wątków dotyczących sekularyzacji sacrum oraz relacji pomiędzy trzema sferami: sacrum, profanum oraz divinum. Sekularyzacja sacrum jest obecnie poważnym problemem $\mathrm{w}$ pracy pastoralno-wychowawczej, zwłaszcza w kontekście postmodernistycznego „zwrotu antropologicznego". Problem z kategorią sacrum jest głęboko zakorzeniony nie tylko w szeroko rozumianej zachodniej kulturze i cywilizacji, ale i w samej społeczności chrześcijańskiej. Jedynym lekarstwem na kryzys sacrum (i w rzeczywistości także profanum) jest pamięć o sferze divinum, o samym Bogu, który nie jest tylko mitem lub filozoficzną koncepcją, ale realną osobą. W tym celu należy kłaść szczególny nacisk na prawdziwe chrześcijańskie życie i wychowanie, pełne miłości, wiary i nadziei. Tylko prawdziwy chrześcijanin może być wiarygodnym świadkiem Chrystusa.
\end{abstract}

Słowa kluczowe: Sacrum; profanum; divinum; wiara; chrześcijańskie wychowanie. 
